\title{
Spiritual Dimension of Land Identity Crisis in Igboland of Nigeria: An Ethical Reflection
}

\author{
Patrick E. Nmah* \\ DOI: http://dx.doi.org/10.4314/ujah.v12i2.6
}

\begin{abstract}
There have been series of redefinition of right to land in various countries following various land reforms by various governments in the African continent to the extent that there are confusions regarding what the right to land ownership standards are culminating in pressures and contestations over land between and betwixt groups, especially when the aboriginal right to land is put into question. Violent conflicts become almost normal among the contending groups. It is due to this background and observation that this paper examines the present situation and disadvantages of the socalled land reforms in Nigeria that was imposed on the spiritual life of Igbo people and how it is related to conflict situations. Both the analysis of the literature collected, anthropological etic and emic perspectives are utilized to source for information required for this research work. This paper presents the Igbo ethical conceptualization of land ownership with regard to spiritual identity.
\end{abstract}

\section{Introduction}

In the course of this research work, it will be expedient to apply land identity theory of religion to Igboland and to show how the members of those societies are consciously or unconsciously engaged in the task of seeking individual as well as collective identity. The fundamental definition of religion following Mol is that religion defines man and his place in the universe posited Nmah (2004). Igbo communities have been undergoing a process of stress in all ramifications. 
Issues involved include right to property and settlements which have been the major causes of various conflicts, especially with respect to land and land resources. The definitions and uses of the term identity are legion, especially among religious scholars and social psychologists. To an extent, the term identity refers to who somebody is or what something is. It could be regarded as self-realization or selfawareness as awareness could be defined as consciousness of one's existence and characteristic, usually in relationship to other people or objects. Consequently, self-identity has to do with self-esteem and recognition by others. Identity has both biographical and spatial dimensions in that it deals with either what a person or thing are essentially, his or its place in a universe of interactions and relationships.

The idea of "spirituality" or "holiness" is universal in all religious beliefs and practices, "purity" and "impurity", "clean" and "unclean", the "sacred" and the "mundane", and the "spiritual" and the "material". Nottingham (1968), a sociologist, observed that, "in all known societies there exists a distinction between the holy and the ordinary or, as we often phrase it, the sacred and the secular or profane" (p.4). The field of religion is the field of "sacredness" or "holiness". In Christianity, there is the well known injunctions, "For I am the Lord your God; consecrate yourselves therefore, and be holy, for I am holy" (Lev. 11:44). "You, therefore, must be perfect, as your heavenly Father is perfect" (Mt. 5:48).

One of the factors of spirituality in Igboland is land (ala). Ala is the fount of human morality, and its violation attracts legal sanction. Alienation of people from their ancestral land, and similar offences against ala (land), must be purged by rite to it. Ala (land) deprives evil men of their lives, and its priests are the guardians of public morality. The notion that land and other issues surrounding land are at the centre stage of almost every conflict situation in Igboland 
cannot be taken for granted. Many theorists have explicated the interwoven relationship between land and conflicts in Africa from economics, political economy and spirituality cum ideological perspective. Based on the economic assumptions, Adedeji (1999) admits that competition for economic resources is an important factor in conflict, but is not the only one.

Beyond the physical conceptualization Igbo people see land as an object that has spiritual and other implications. According to Bohannan (1953), it is an aspect of man's socio-political status. Obioha (1992) posited that societies in Africa perceived land as a common property that serves as a link between the living, the dead and the unborn members. It is a common holding and a piece that binds generations past, present and future together. The living members of African societies hold that ancestral land handed down to them by the dead in trust for the future members. The above statements suggest the notion for sacredness of land in Igboland and Africa per se. That is why every Igbo man struggles to own land in order to actualize his political relevance and existence in Igboland.

\section{A Sketchy History of Igboland}

The Igbo nation is a very numerous ethnic group, which is divided into a very large number of small village democracies. According to Uchendu (1965), the Igbo have a culture and also a history which is unwritten history and it is the task of the culture historians to piece them together. An analysis of demographic pattern, trait lists and other cultural features combined with available local traditions, lead us to two interrelated hypotheses of Igbo origin viz:

1. That there exists a core area which may be called the nuclear Igboland, and 
2. That waves immigrant communities from the north and west planted themselves on the border of the nuclear Igboland as early as the fourteenth or the fifteenth century.

Uchendu (1965) and Nwabara (1977) stated that the origin of the Igbo like any other ethnic groups in Nigeria is unknown and therefore many suggestions bordering on guesswork and fancy have been made. The belt formed by Owerri, Awka, Orlu and Okigwe axes constitutes the nuclear area. These people, it was observed, moved into Nsukka-Udi highlands in the north and into Ikwere, Etche, Assay and Ndoki in the south. The eastern Isuama claimed to have come from this center with Ngwa traditions pointing to their secondary migration from Mbaise. The movement of the Igbo to the north, south, east and west tended to homogenize Igbo culture. The reasons for the migration include procuring land, found independent villages, the pressure of population in certain areas and the natural disasters that made continued settlement in some places inauspicious.

Onitsha, Oguta, and the Ezechima group of villages in western Igbo claimed affinity with the Bini and have their kingship institution to show as evidence of descent. Today the word Igbo may be used in three senses namely to refer to Igbo territory, to the domestic speakers of the language, and to the language spoken by them. The origin of the Igbo which is based on outside origin hypothesis, which points to the Jewish origin of the Igbo, and ancient origin hypothesis, which is internal, shall be appreciated by stating that the Igbo origin is unknown. Irrespective of the origin narrative, one thing is obvious that the Igbo society existed for centuries before the advent of the white man and long before the birth of Nigeria as a nation state. 


\section{Land (ala) as a Symbol of Spiritual Identity in Igboland}

In the quest for faithful approaches to understanding and responding to the theme of justice, peace and the integrity of creation, a document associated with land (ala) entitled, "The theology of life", was developed. Long before the western education was introduced among the indigenous learning systems, there were other means of education in Igboland especially informal system of education. Through these educational methods of learning, children were taught livelihood and defense skills, the norms and mores of the society, as well as their history and culture such as myths, songs, dance, and legends and so on. They are taught the names of plants, the significance of herbs to human life and their relationship with the earth. In politics, religion, culture and social life, the earth (ala) has a significance role to play. Education mirrored and affirmed the distinct spiritual identity of the Igbo people. Today, indigenous Igbo people want to revitalize these basic spiritual elements of their learning systems, while they learn new spiritual ideas and skills to survive in their rapidly changing environment.

Ala spirituality for centuries past among Igbo people has been ritual related to the earth, regarded often as a female goddess or occasionally as a male. This somewhat impersonal figure is worshipped as the omnipresent protector of the earth (ala), the giver of fertility, the guardian of marriage, family and the home (Barrett, 1970). Such fertility cults, together with the ancestral cult, were responsible during the unstable period of colonial missionary impact for much of the stability that remained in tribal societies. Ala cult also attracted the attention of missions. For some missions the cult of the Virgin Mary became almost indistinguishable from that of the local earth goddess.

Latter missions took however a far stricter line. In the rich agricultural sub-cultures of Igboland, such as in Ngwa, 
Mbaise, Mbano, Etiti, Mgbo, Nkanu, Isuikwuato, Ezeukwu, Ishagu, and so on, the worship of the earth deity was attended by fertility rites unacceptable to the nineteenth-century European ideas of morality. But this is similar to Canaan fertility cult (Baal and Ashtoreth cf. Njoku and Mmaji of Ngwa and Mbaise).

For the Igbo the earth mother is ala, the greatest deity after Chukwu, the heavenly creator (Parrinder, 1976). She is as near to them as the ancestors, for they are buried in her pocket or womb. Ala sends the dead back again in rebirth and she is the spirit of fertility both for the family and for the land. Barren women, or mothers whose children have died, pray to Ala for children, and men ask her for success in trade and increase of their livestock. So Ala is a kindly spirit and she helps her children if they are troubled by other deities. But if people offend her and disregard repeated warnings, she will punish them and a hardened evildoer may receive the final humiliation, refusal of burial in the earth.

The ala is generally sacred, for it belongs to the earth spirit, and to the ancestors as well as to the living community; attempts at selling land are unpopular and in olden days they were impossible. This was a major cause of the Mau Mau troubles in Kenya (Parrinder, 1976). The Igbo dislike selling land because of their reverence for ala, and they appease her if it has to be done. Their ancestors founded the ihu ala (face of the earth), which became sacred for the people and was the place where major decisions, such as warfare or ritual oaths were made and strictly respected.

While land is the birth right of every Igbo male, it has a communal dimension whereby all members of the community are expected to share its resources, especially in rural areas, under some form of traditional authority. Traditional authority from an African cosmology is very central and important because, despite the fact that it is a 
unifying force, the eldest community leader is seen as a steward with divine authority over land. The invasion of the colonial masters and missionaries was nothing other than an insensitive, greedy and cruel method for dispossessing Igbo people of their religion, land and culture. Land was acquired with total disregard of traditional beliefs and cultures underpinning the spirituality of the Igbo nation. The traditional homes were stripped of their dignity, many lost their identity, language, cultures and spiritualities. In this sense, land was acquired and used as political and ecclesiastic tools for dominance. Regard was also not given to earth goddess (ala).

\section{The Relevance of Land (Ala) as a Spiritual Identity vis-à- vis Igbo Christian Faith}

According to Igbo belief and tradition, ala (land) is a gift from God (Chukwu), and from ancestors has not left them. They continue to see themselves as stewards of God's resources as in Genesis 1:28-30, especially of communally owned land. Ala (earth) is valued as a source of livelihood. Even though ala ownership has been men's domain, it is interesting that many women, with the support of Nigerian constitution, have begun to acquire land in spite of traditional prejudices. Ala (land) produces food and water, which give life to all living things. The sacredness of ala in Igboland is further linked in it. The custom of asking for rain or making rain through the help of ancestors and God still features strongly in some Igbo communities. This is because the stones (nkume-miri) used in making rain are excavated from the land and buried at a particular spot of the land. Majority of the Igbo communities continue to make sacrifices before they eat from the harvest especially during a new yam festival to thank God and their ancestors. Sacred mountains, hills and other lands are used as the abodes of certain deities. 
There is a very close link between Igbo faith and their relationship to the ala (land).

The Bible, particularly the book of Exodus, started with a story of a community in transit, a community in motion on a journey that has been prompted by a promise, a community with a goal, a goal that has taken precedence over everything else in their lives, the search for a land they could call their own, a piece of land they could call their traditional home (Genesis 12-Judges 16). These people's journey is not merely a product of their intellectual genius or innovation. It is a process in which God is involved, a process in which the role and presence of God is paramount. In consequent, the journey in which these people are involved is not just physical, but also spiritual. It is a spiritual process undertaken in obedience to God's calling. It is an exercise undertaken in trust to the promise that God has made. The spirituality that motivates drives and even propels the Israelites is therefore, at least primarily, a spirituality of possessing their own indigenous land. A piece of land (ala) in their own traditional name to which their identity as a people is linked or a piece of land from which their identity can be traced. In Egypt, they have leader, people and law, but there was no land to complete their nationhood.

This link between spirituality and the ala (land) seems to apply, not only to ancient Israel. Rather, it is a common denominator in the life and faith of all traditional religious communities Igbo inclusive. An abstract spirituality that does not spring from the people's daily lives, work and experiences seems to be alien and inconsistent with the biblical tradition. Spirituality seems to be always socially, culturally and even economically conditioned, determined and shaped by the God's given ala (land).

Historical, cultural, magical and religious beliefs and emotional meanings are attached to land, which exist between 
individuals or groups and the land they inhabit. Across the societies and continent in Africa, the communal ownership of land is sustained by some factors, which range from religious ideology, politics, and economy. In an attempt to describe these underlying features, Colson (1971) highlighted the fact that land was bounded up with the religious ideology, politics, and economy. The existence of the rule of inalienability of land in Igboland is one of the factors that sustains communal claim to land. Individuals who own lands do not have the absolute right to dispose such lands, because of the religious or magico-religious attitude of Igbo nation towards land. Price (1933) found that in most African societies, the myth of the original ancestor according to which common origin of the members of a community renders inconceivable the giving away of ancestral land to non-autochthonous individuals or groups community and family land have been held inalienable from a desire to preserve it for the requirements of the owning group, present and future.

In Nigeria and Ghana, major land reforms took place some years after independence. But with particular reference to Nigeria a new land decree number 6 was promulgated on March 27, 1978 by the then federal military government of Nigeria. The main rationale and philosophy of the land use decree, in their words, was to remove the obstacles in the path of fast economic and social development of Nigeria. Hitherto, it has not been easy to acquire land for development purposes. Governments, corporate bodies and even individuals, requiring small parcels of land for setting up industries or housing estates were denied the opportunity. Land prices were exorbitant and arbitrarily fixed.

Suggestively, Okpala (1979) and Nwaka (1979) believe that what Nigeria needed was not much a new law, but a more efficient way of implementing existing land 
control measure. In practice, the various post-colonial land reforms in African nation states technically, but non-violently transferred the ownership of land from the original owners to the capitalists who control the government. The processes and requirements for the masses, acquisition of Certificate of Occupancy in Nigeria requires some amount of money to be paid, which in most cases is beyond the reach of the ordinary citizen.

Because of all these impediments to claim of ownership of land in Nigeria, and most likely in other nation states in Africa, the peasants especially those in the rural areas are thrown into state of confusion, hopelessness and helplessness on land that they have acquired mainly through inheritance. A land that is their inheritance and what they can boast of. A land that serves as their identity, their self-awareness and as a spiritual value is now in the hands of strangers called government or immoral politicians who used their positions as advantage to acquired land in the name of mirage industries. And politicians who do not wish them to actualize their full self.

\section{Igbo and their Socio-ethical Relationship to Ala (Land)}

Igbo traditional society perceived its cosmos as created by Chukwu (Supreme Being) who is manifested in a variety of ways viz as anyanwu (the sun), his power, knowledge and omnipresence are revealed; as agbara (deity), who is manifested in the fertility of the earth, animals and human beings. As chi (god), he empowers and strengthens human beings. As okike (creator), he is manifested in the creation of everything visible and invisible, which is a never-ending process. In the three dimensional perception of space and the cyclical perception of time the human world, uwa, is dominated by the earth-goddess (ala). 
The Igbo word which encapsulates all these notions is nso, which could mean holy, sacred, to be avoided, forbidden, restricted, or abominated. This last sense is more forceful when qualified with ala (earth, home god). It becomes an act which the community would regard as not just detestable, but an offence against the earth divinity, ala. The earth sustains life and this elevates the earth goddess into great prominence, and since the offences are committed on the earth, murder, sexual offences, abusive language and allegations among others are nso (taboos). Offenders would propitiate the earth goddess, and the cost of the propitiatory rites could serve as deterrence.

The ala (earth goddess) nurtures, but punishes abominations. Similarly ancestors protected and mediated for the welfare of human families, but exacted libations, sacrifices, and second burials. These personal, warm and caring images were obviously a control on human political agents, who, as stewards and managers of the divine estates (lands), would want to rule as august and transcendent beings. Thus the land as an institution inculcates a personal awareness of the social dimensions and gravity of serious moral lapses, and serves thereby as a useful moral deterrent and educator of conscience. The complex interplay of land both as an economic resources and as a basis of the political super-structure cemented, tied and broke bonds among nations, ethnic groups, religion, genders and classes in the pre-colonial and independent periods.

The centrality of land to Igbo economic development has been tied to the significance of land resources to cultural and traditional practices. Rituals related to rain-making, marriage, naming ceremony, thanksgiving and prayer have historically been tied to the land in Igboland. Control of ala (land) was however linked to the complex interplay of economic, social and political power identity. 
Ala (land) as a source of food is one of the most basic human needs. Its sources, generation and security have always been the most primary preoccupation of all human communities. Whatever, therefore, threatens Igbo people's source of livelihood threatens their very spiritual existence. It threatens everything they are, socially, economically, morally as well as their spiritual nature. Whatever that threatens the people's primary source of livelihood is a spiritual threat. Anything that deals with the people and the circumstances under which they live their life on earth is a spiritual concern. In other words, it always either directly or indirectly shapes their view of God. Consequently, anything that threatens the people's source of livelihood can never be justifiable either morally or theologically.

Ala (earth) serves as a source of shelter. Every Igbo man needs a place he refers to as a home. A place where he is in control of the land resources such as water, soil, petroleum and other natural resources associated with land, a place of one's root. Ala (land) serves also as a source of tools. In the biblical tradition, when a community was struck by some hardship like a human epidemic or one that affects crops or livestock such as bird flu (or even natural phenomena such as drought, floods, volcanic eruption and the likes) the cause was always traceable to the possibility of human sin. With the advances in the $21^{\text {st }}$ century in science and technology such events are interpreted differently. Technology has helped to identify other causes, and the Igbo understanding of God and God's place has changed. Technology - the kind of tools that people have at their disposal - is in essence their power, and depriving them of the basic source of their tools is the crudest form of disempowering them. Alienating the people from the land is therefore really and truly a political as well as spiritual alienation. Ala (earth) serves also as a burial ground. The places at which Igbo people down the centuries have buried 
their dead are of great historical as well as cultural significance to the life journey. They serve as important signposts for the journey that still lies ahead of Igbo. Signs, symbols and shrines have always had a very important religious value. They have always been regarded as a holy ground of some kind. Denying them access to such important landmarks in their cosmology is a terrible misunderstanding of their cultural roots as well as a denial of a fundamental religious right.

\section{Conclusion and Recommendations}

Examining the various land reform policies in postcolonial Igboland proves that the poor rural peasants are thrown into state of confusion on what actually obtains with regard to land. Lands they believed to be the property of their inheritance does not really belong to them as expected. Under this situation, they do not have control over their land because of decree 6 . They feel psychologically dispossessed with a deep spiritual feeling of worthlessness in their society. Lands are taken over by scrupulous politicians who in governance for frivolous or non-existing industries, but for their egocentric adventure. In most cases, such lands taken by them are not been compensated for or at most the compensation is not adequate. The major point of contention is to resolve the dilemma arising from the need to acquire land for the economic development of the country Nigeria as a nation state.

A free market economy is important in the economic development of country. The economy should not be allowed to degenerate into serious spiritual barrenness, alienation and poverty to the people. And policies and affirmative action programmes must be developed to minimize and reduce poverty in Igboland. One of the consequences of redefinition of land rights is the incessant land disputes such as that of 
Aguleri and Umuleri, in Anambra State, and inter/intra ethnic feuds over land as observed between Abia and Akwa Ibom State. The situation as it turns to be at the moment requires efficacious practices to handle the uprisings. It is noteworthy that unless something meaningful and urgent is done in this direction, there appears to be no end to the problem. In the process of acquiring a land, majority opinion of the affected citizens should be ascertained in order to avoid impending clash. Compensation should be paid to the people whose lands are acquired for development purposes or in public interest.

The earth is "ecumene" which a Greek geographer applied to mean permanently inhabited areas of the earth's surface (Getis, Getis and Fellmann, 2000). Land determines a person's or group of persons' social status by income, religion, education, ethnicity, occupation and home value. For some groups, ethnicity is a more important residential location determinant than social or family status. Areas of homogeneous ethnic identification appear in the social geography cities as separate clusters or nuclei. For some ethnic groups, cultural segregation is both sought and vigorously defended, even in the face of pressures for neighborhood change exerted by potential competitors for housing space. This is turn affects the land usage. Again, hazardous waste from the villages especially from the cities in Igboland should be deposed far from human habitation areas.

The Environmental Protection Agency (EPA) has classified more than 400 substances as hazardous, posing a threat to human health or the environment. Industrial wastes have grown steadily more toxic. Currently, about $10 \%$ of industrial waste materials are considered hazardous. Every family that either uses or produces radioactive materials generates low-level waste, material whose radioactivity will 
decay to safe levels in 100 years or less. Nuclear power plants produce about half the total low-level waste in the form of used resins, filter sludge, lubricating oil, and detergent wastes. High-level waste can remain radioactive for 10,000 years and more such as plutonium which can stay dangerously radioactive for 240,000 years. It consists primarily of spent fuel assemblies of nuclear power reactors termed civilian waster - and waste generated as a by-product of the manufacture of nuclear weapons, or military waste. Other waste materials that are quietly affecting environment in Igboland include aquatic wastes, telecommunication masts and spent recharge cards. The federal, states and local councils should find better means of handling these waste materials so as to avert unforeseen calamity.

In conclusion, since ala is one of the pivots of Igbo traditional spirituality, any government land reform policy or person's or group's land policy to be made regarding the use of such land should put into consideration the effect of such decision on the spiritual life of the people.

\section{References}

Barrett, D.B. (1970). Schism and Renewal in Africa: An analysis of six thousand contemporary religious movements. London: Oxford University Press.

Buch, R. and Szeftel, M. (2000). Struggle for land. Review of African political economy. No. 84: 173-180.

Collier, P. and Binswanger, H. (1999). Ethnic loyalties, State Formation and Conflict: A background for the Africa in the $21^{\text {st }}$ century project. Washington D.C.: World Bank. 
Colson, P. (1983). The impact of colonial period on the definition of land rights in colonial Africa. London: Oxford University Press.

Dike, A. (1983). Land tenure system in Igboland. In International Review of Ethnology and Linguistics, Anthrop, Vol. 78, 40-52.

Egunjobi, R. (1991). An empirical study of the implementation of the Nigeria land use policy: Social science council in Nigeria/Ford Foundation Research Project. Abuja: SSCN.

Elias, T.O. (1951). Nigeria land law and custom. London: London University Press.

Getis, A.; Getis, J. and Fellmann, J.D. (2000). Introduction to Geography. New York: Edward Bartell.

Ilogu, E. (1974). Christianity and Ibo Culture. Leiddn: E.J. Brill.

Nottingham, E.K. (1968). Religion and Society. New York: Random House.

Nwabara, S.N. (1977). Iboland: A century of contact with Britain, 1860-1960. London: Hodder and Stoughton.

Nwala, T.U. (1985). Igbo Philosophy. Lagos: Literamed Publications.

Obi, S.N. (1963). The Igbo of southeast Nigeria. New York: Holt, Rinehart and Winston.

Parrinder, G. (1976). Africa's three religions. London: Sheldon Press.

Tolumin, and Quan (2000). Evolving land rights, policy and tenure in Africa. London: IIED.

*Dr. Patrick Nmah is of the Department of Religion and Human Relations, Nnamdi Azikiwe University, Awka. 